\title{
THE EFFECT OF INTELLECTUAL CAPITAL ON KNOWLEDGE MANAGEMENT: STUDY ON AGRICULTURE ORGANIZATION EXPERTS IN KURDISTAN PROVINCE
}

\begin{abstract}
This study aimed at exploring the effect of intellectual capital (IC) on knowledge management (KM) among Agriculture Organization experts of Kurdistan Province. Statistical population of this study consisted of all Agriculture organization experts in the Kurdistan province of Iran ( $\mathrm{N}=326)$. Using Cochran's sampling formula, 63 farmers were selected as a sample. Respondents were selected by using Stratified random sampling method. For increasing reliability of the findings, 125 questionnaires distributed among experts, ultimately 101 questionnaires completed and analyzed in SPSS software. The instrument of the study was a questionnaire which its validity was confirmed by a panel of experts and its reliability was established by calculating Chronbach's Alpha Coefficient $(\alpha>0.7)$. Data analysis was performed by SPSSwin18 software.

The Results of this study showed that level of IC and KN was moderate among Agriculture organization expert. Moreover, Results of correlation analysis showed that there is a significant positive relationship between indicators of the IC (human, structural and relational) and KM. Finally, the results of stepwise multiple regression analysis showed that the indicators of IC (human, structural and relational), they can to explain $4.6 \%$ of the variance in the dependent variable.
\end{abstract}

\section{Farhad Mohammadi Kanigolzar, Moslem Savari,}

Nasser Motee

University of Tehran

farhad.mohammadikani@gmail.com

ARTICLE INFO

Article type

Full research paper

doi: 10.7160/eriesj.2013.060102

Article history

Received: November 5, 2012

Received in revised form: March 3, 2012

Accepted: March 13, 2013

Available on-line: March 31, 2013

\section{Key Words}

Knowledge management, intellectual capital, knowledge creation, innovation, Kurdistan 


\section{Introduction}

Knowledge has become a powerful tool for corporate competition (Shih et al., 2010), and successful companies do not gain benefits with only tangible assets, and they mainly rely on access to intangible information and knowledge creation as their major resources for success (Guthrie, 2001). Enormous economic and business theorists express that knowledge is the only resource that is difficult or even impossible to duplicate or copy. So it has a good knowledge of the country itself, is unique. Obviously, such a resource must be protected, rehabilitated and managed and any technique is used that provides it better growth and spread (Adli, 2005).

So in this conditions knowledge application refers to that knowledge that has been shared by members of a firm is utilized in innovation (Yli-Renko et al., 2001). Through utilizing the diversified tacit knowledge grasped by organizational members, knowledge application enables firms to respond timely to the technological changes by applying the knowledge generated into products or processes to innovative activities (Song et al., 2005 \& Li, Yuan, 2009). Hence Li, Yuan (2009), provides a similar definition of organizational knowledge and also he says that the human element is as the most important element in creating and applying knowledge in organizations. Furthermore, insists that the knowledge is formed and used through of circulation between interaction and individuals in an organization and communication between them. The profile of $\mathrm{KM}$ is one of the fundamental ways of guarantying competitive benefits in the global marketplace, has flourished in the recent period of time (Davenport and Prusak, 1998; Drucker, 1988; Lesser and Prusak, 2002; Nonaka and Takeuchi, 1995; Scarbrough et al., 1999). Generally, KM is all about methodically developing, preserving, and making access possible to an enormous stock of knowledge that subsists within organization (Prusak, 2001; Roos and von Krogh, 1996). Several studies have been done on knowledge management in the world, But since, this study has conducted for Agriculture Organization (as a government agency) hence more attention to the studies has been in this field. For example, a study conducted about of knowledge management in government agencies, was considered Relationship between organizational components (organizational culture, organizational structure, technology, human resources and political orientation) and the ability of knowledge creation and knowledge transfer in the Ministry of Entrepreneur Development of Malaysia. The Results show that there are a significant correlation between these variables and the ability to generate and transfer knowledge (Skyreme, 1998).

Organizations employing knowledge management strategies they have provided to innovation in processes, activities, products and services. So, recognition of factors affecting enterprise knowledge management is one of the initial actions in the effective use of the organization's intellectual resources. Training organizations have knowledge within their inside and after processing the information into knowledge according to routine method, incorporation of knowledge with values, strategies and experiences will be basis of decision-making and future actions of organization (Bahrami \& et al., 2011).

Davenport and Prusak (1998) note that technological advances in data processing, communication, and transportation, as well as employed demand and strategists' planning have made the world economy change very fast. It has been the biggest wave of changes since the Industrial Revolution. The economy is dubbed 'knowledge economy', as the prime commodities are knowledge and information (IC). Knowledge creates and leverages the intangible value of companies that is IC. Teese 
(2000) notes that with the growth of the knowledge-economy, the intangible assets of the firm and its IC are the keys to achieving sustainable competitive advantage. Hence in the new economy, intellectual capital has been described as intangible assets as well (shojai \& et al, 2009). Intellectual capital is defined as intangible assets which include technology, employed information, brand name, reputation and corporate culture that are invaluable to a firm's competitive power (Low and Kalafut, 2002),). Hence, IC consists of (1) tacit knowledge and innovativeness of the employees, (2) infrastructure of human capital (i.e. good working system, innovation) and improvement processes of structural capital and; (3) external relationships of the firm (i.e. employeds' capital). These are the key drivers of organization performance and creation of future wealth. (Bontis et al., 2000; Riahi-Belkaoui, 2003). In realizing the goals of a progressive and dynamic financial sector and the desire to become a knowledge-based economy, greater efforts must be directed to building human intellectual capital (Lepak and Snell, 1999). Furthermore, intellectual capital can be viewed as a mix of human capital, structural capital and employed capital (Bontis, et al; 2000, Riahi-Belkaoui, 2003). Figure 1 illustrates this:

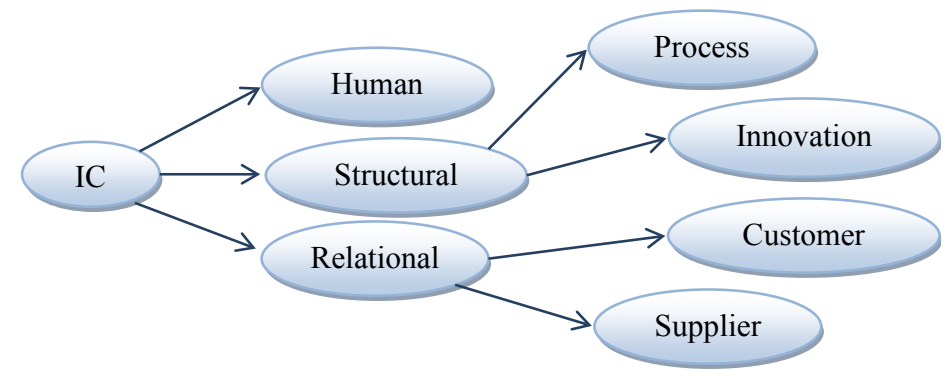

Figure 1: division of IC
Human capital generates innovation - whether of new products and services or improving business processes. Structural capital is the knowledge that belongs to the organization as a whole in terms of technologies, inventions, data, publications, strategy and culture, structures and systems, organizational routines and procedures. Finally, employed capital is the firm's value of its franchise, its ongoing relationships with the people or organizations to which it sells, like market share, employed retention and defection rates, and per employed profitability. Only structural capital, which is owned by the firm, and is assumed not to be reproduced and shared, is the best approximation of intellectual capital. Stewart (1997) indicated that IC refers to the aggregation of all knowledge and competences of employees that can bring about competitive advantages for companies. Any intellectual materials that can create wealth, such as knowledge, information, techniques, intellectual properties, experience, learning ability of organizations, and employed relationships, can be the most valuable assets and most advantageous tools in competition.

Most previous KM literatures addressing IC have focused on the correlation between IC and organizational performances (Chong and Lin, 2008; Ho, 2009). There are relatively few discussions on the relationship between knowledge management and IC, and even fewer studies on such a relationship in the agriculture organization. The core competitiveness of the banking industry is highly reliant on the ability of management teams to systematically manage knowledge and experience. It also depends on whether they are able to create sophisticated skills catering to the IC of their organization to effectively manage risks and create profits. The accumulation of IC and knowledge creation is closely related (Rezgui, 2007; Lin,et al., 2008). IC is generated via systematic integration of knowledge (Shih et 
al., 2010). Alo, The study conducted by Kurdabady Salehi \& et al(2010), that has done to Explain the relationship between intellectual capital and knowledge creation as the insurance company. The survey results indicate that there is significant relationship between intellectual capital and knowledge creation. In addition, Shih \& et al (2010) showed that the performance of knowledge creation has significant influence on the accumulation of subsequent human capital. Cognitivists and connectivists are considered the main knowledge creators in the banking industry. The performance of human capital exhibits significant influence on structural. Capital and employed capital. The performance of employed capital reports significant influence on the formation of structural capital.

At present now, Iran is as a country rich in natural resources, abundant capital and labor activist is desirable. so, needs to group of skilled, experienced, active, educated and professional in all fields such; economic, social and cultural. Therefore, the directors which they are aware and competent are necessary for coordinate human and material resources that they facilitate to achieve economic, social and cultural rights in the country. Therefore, to achieve success in a complex and uncertain situations and in situations where time is constraints, $\mathrm{KM}$, learning and development in organizations is presented as a solution. In this regard, IC is as one of the most valuable resources that can be considered as an asset in the organization. Based on this study, investigate the effects of IC on KM in the agricultural organization experts of Kurdistan province; to achieving the goals will be pursued the following specific:
1. Evaluation of personal and professional characteristics of experts

2. Assessing IC and KM sample Experts

3. Investigate the relationship between Aspects of IC and KM

4. The effectiveness of each of the dimensions of IC on KM

\section{Materials and methods}

The design of the study was a descriptive survey that done by single cross-sectional study. Statistical population of this study consisted of all Agriculture Organization experts in the Kurdistan province of Iran (N=326). Using Cochran's sampling formula, 63 farmers were selected as a sample. Respondents were selected by using Stratified random sampling method. For increasing reliability of the findings, 125 questionnaires distributed among experts, ultimately 101 questionnaires completed and analyzed in SPSS software. The instrument of the study was a questionnaire which its validity was confirmed by a panel of experts and its reliability was established by calculating Chronbach's Alpha Coefficient $(\alpha>0.7)$.

The questionnaire consisted three parts that include: 1 . personal, social, and economical characteristics and 2. A scale was used to measure intellectual capital. Of course in this section was used of the intellectual capital model Betis (2001) then prepared 18 questions in five-degree Liker range (1 - totally disagree to 5 - completely agree). That is measured three indicators from intellectual capital: structural capital, relational capital and human capital. 3. In this section the questionnaire used of Knowledge Management models Lawson (2003), and Based on prepared of 30 questions in five-degree Liker range (1 - totally disagree to 5 - completely agree). That is measured 6 indicators 
from KM: Organizational knowledge, knowledge application, knowledge storage, knowledge creation, knowledge capture and dissemination of knowledge.

In order to, estimate the reliability of the questionnaire Cronbach's alpha coefficient was established. For each part of the questionnaire Cronbach's alpha coefficients was over 0.7. Thus, the reliability of the questionnaire was excellent for research. Data analysis was performed by SPSS ${ }_{\text {win18 }}$ software. Thus, in the part of descriptive statistics were used of: frequency, percentage, mean and standard deviation and in the inferential statistics used of correlation coefficient and multiple regressions.

\section{Results and discussion}

\section{-Personal and professional characteristics of experts:}

The results of the study showed that the average age of experts was 31.12 years old and SD was 7.43. Which the youngest of them have at 23 years old and the oldest was 59 years. The average farming experience was 11.4 years and a SD 7.23 respectively. Based on the findings of the among survey population 69 percent were educated in agricultural fields and 31 percent in non-agricultural fields.

\section{- Assessment of intellectual capital and knowledge management among experts:}

In order to evaluating the level of intellectual capital and its indicators and also, to prioritize the indicators of intellectual capital among experts was used from the mean and coefficient of variation. The results of this section are showed in table 1.

\begin{tabular}{lcccc}
\hline Indicators & Mean & SD & CV & rank \\
\hline - structure Capital & 4.44 & .721 & 16.2 & 1 \\
- Relational capital & 3.98 & .698 & 17.5 & 2 \\
- Human capital & 4.25 & .753 & 17.7 & 3 \\
- Intellectual capital & 4.02 & .705 & 17.5 & - \\
\hline
\end{tabular}

* Scale: 1-Strongly Disagree to 5-Strongly agree

Table 1: Ranking of intellectual capital indicators among experts

According to findings on table 1 results shown that the level of intellectual capital and its constituent indicators among experts is more than average. Therefore, we can say that the Agriculture Organization experts they have favorable in an intellectual capital. Also, the results in Table 1 indicate that Structural capital indicator is located from higher priority than other indicators of intellectual capital.

In order to evaluation the level of Knowledge management and its indicators and prioritize $\mathrm{km}$ indicators among sample experts C.V. statistical method was used. The results are given in Table 2.

\begin{tabular}{lcccc}
\hline Indicators & Mean & SD & CV & rank \\
\hline Knowledge creation & 4.01 & .688 & 17.1 & 1 \\
Organize knowledge & 4.03 & .701 & 17.3 & 2 \\
Power of knowledge & 4.47 & .780 & 17.4 & 3 \\
Knowledge dissemination & 3.95 & .745 & 18.8 & 4 \\
Storage knowledge & 3.85 & .752 & 19.5 & 5 \\
Application of Knowledge & 3.52 & .695 & 19.7 & 6 \\
\hline KM & 3.87 & .706 & 18.2 & - \\
\hline \multicolumn{4}{c}{${ }^{*}$ Scale: 1-Strongly Disagree to 5-Strongly agree }
\end{tabular}

Table 2- prioritize indicators of KM among agriculture organization experts 
In the table 2 results shown that the mean of Knowledge management level and its indicators among sample experts are higher than average. Therefore, we can say that the Agriculture Organization experts relatively are good from level of knowledge management. In addition, the results of table 2 shown that the among indicators of forming a knowledge management: Indicators of knowledge creation and knowledge organized respectively are higher priority than other indicators of constructive knowledge and also indicator of knowledge application and knowledge of storage, respectively are lower priority than other indicators of constructive knowledge among agriculture organization experts.

\section{-Examine the relationship between dimensions of intellectual} capital and knowledge management

In order to examine the relationship between intellectual capital indicators and knowledge management, among Agricultural Organization experts was used of the Pearson correlation coefficient. The results are shown in Table 3.

\begin{tabular}{lcc}
\hline & \multicolumn{2}{c}{ KM } \\
\cline { 2 - 3 } Dimensions & Sig & $\mathrm{r}$ \\
\hline - Structure Capital & 0.000 & $.540^{* *}$ \\
- Relations capital & 0.000 & $.467^{* *}$ \\
- Human capital & 0.000 & $0.463^{* *}$ \\
\hline \multicolumn{2}{c}{${ }^{* *}$ Significance at $\mathrm{P}<0.01$}
\end{tabular}

Table 3 - examine the relationship between IC indicators and knowledge management
Based on the findings presented in Table 3, Correlation analysis showed a significant positive relationship the level of $1 \%$ between each of the indicators of intellectual capital and knowledge management.

- Determining the effect of each of the dimensions of IC on KM

In order to determination the effect of each of the dimensions of intellectual capital on knowledge management used of Stepwise multiple regressions. The stepwise method of regression analysis is the method in which the most powerful variables enter into the regression analysis and equation and this continues until the error of significance test reaches 5 percent (Kalantari, 2010). Then, in this study the dimensions of intellectual capital (human, structural, relational) as independent variables and $\mathrm{KM}$ as the dependent variable were entered into regression analysis. The results are shown in tables $(4,5$ and 6$)$.

\begin{tabular}{lccc}
\hline Statistical indicators & $\mathrm{R}$ & $\mathrm{R}^{2}$ & $\begin{array}{c}\text { Adjusted } \\
\text { coefficient }\end{array}$ \\
\hline The coefficient & .752 & .624 & .502 \\
\hline
\end{tabular}

Table 4 - Multiple correlation coefficients on the effective of IC with $\mathrm{KM}$ respondents

Based on the findings presented in Table 4, the multiple correlation coefficients $(\mathrm{R})$ were equal to 0.752 that Indicating the high correlation between the dimensions of IC and KM among respondents. Also determination coefficient $\left(\mathrm{R}^{2}\right)$ was equal to 0.624 . In other words, $62.4 \%$ of the variability dependent variable (knowledge management) was explained by dependent variable (the dimensions of intellectual capital). 


\begin{tabular}{lccccc}
\hline $\begin{array}{l}\text { Changes } \\
\text { in resources }\end{array}$ & $\begin{array}{c}\text { Sum } \\
\text { of squares }\end{array}$ & $\begin{array}{c}\text { Degrees } \\
\text { of freedom }\end{array}$ & $\begin{array}{c}\text { Mean } \\
\text { square }\end{array}$ & F & Sig \\
\hline Regression & 4588.352 & 4 & 1556.852 & 15.321 & 0.000 \\
Remaining & 19852.852 & 165 & 127.658 & & \\
Total & 23548.635 & 185 & & & \\
\hline
\end{tabular}

Table 5 - Estimated regression model using the $\mathrm{F}$ (variance analysis)

In the table 9 results showed that multiple regression models combination of IC (human, structural and relational) can explain the variance related to $\mathrm{km}$, so that the amount obtained $\mathrm{F}$ equal to 15.321 that is significant at $1 \%$ level. Also, result in table 5, represents a significant regression and linear relationship between variables research.

\begin{tabular}{lccccc}
\hline Variables & $\mathrm{B}$ & Std. Error & $\beta$ & $\mathrm{t}$ & $\mathrm{Sig}$ \\
\hline Constant Coefficient & 58.125 & 5.569 & - & $12.324^{* *}$ & 0.000 \\
- structure Capital & .897 & .157 & .457 & $3.985^{* *}$ & 0.000 \\
- relations capital & 1.457 & .241 & .201 & $3.562^{* *}$ & 0.000 \\
- Human capital & .586 & .254 & .119 & $3.002^{* *}$ & 0.000 \\
\hline
\end{tabular}

Table 6 - The impact of Intellectual capital on KM respondents

Given the above results of Table 6, the linear regression equation is shown as follows:

$$
\mathrm{Y}=58.125+0.897_{x 1}+1.457_{x 2}+0.586_{x 3}
$$

That in this equation:

$$
\begin{aligned}
& Y: \text { knowledge management } \\
& X_{1}: \text { structure Capital } \\
& X_{2:} \text { relation capital } \\
& X_{3}: \text { human capital }
\end{aligned}
$$

Based on results in table 6 , Can be seen that the $t$ values of individual regression coefficients are significant at $1 \%$ level. This reflects the strong influence of intellectual capital in knowledge management responds.

Significant results of $\mathrm{F}$ and $\mathrm{T}$ tests indicate the regression model is valid. But the regression equation does not say anything about the relative importance of independent variables. To determine the relative importance of independent variables, Standardized coefficient $(\beta)$ should be considered. This statistics shows the effect of each independent variable separately from the effects of other variables on the dependent variable. Accordingly, the most influential independent variable for the predicting dependent variable, was the variable human capital with $\beta=0.457$ toward other dependent variable (knowledge management). This means that unit changes of standard deviation of the human capital explain 0.457 of unit change in standard deviation of the dependent variable. Based on, other important variables influenced the dependent variable were: relations capital with $\beta=0.201$ and structure capital $\beta=0.119$.

\section{Conclusion}

Based on the results of the literature, knowledge is as the main source for innovation and organizational productivity. Application of knowledge management will lead to innovation in Organizations. Hence, that knowledge management is often known as a main source of Innovation and also is considered the necessity of innovation in organizations. Furthermore, Intellectual capital is as one of the important organizational capabilities that they can help organizations to creates knowledge and its management and also sustainable competitive to other Organizations. Intellectual capital could be affected in knowledge management, employees. Therefore, this study 
aimed at exploring the effect of intellectual capital on knowledge management among Agriculture Organization experts of Kurdistan Province. As well as the correlation between human capital, structural capital, and customer capital, as the three types of IC. That found the following results:

Based on the results between each of the indicators of intellectual capital and knowledge management; Correlation analysis showed a significant positive relationship the level of $1 \%$ between each of the indicators of intellectual capital and knowledge management.

Based on the results of correlation analysis; that there are high correlation between the dimensions of intellectual capital and knowledge management among respondents. Correlation analysis can be described that the intellectual capital of individuals is higher than the level of their knowledge is higher. In addition, multiple regression results showed that the Dimensions of intellectual capital capable of to explain $62.4 \%$ of the variance in the dependent variable $(\mathrm{km})$.

Finally, the results showed that the development of intellectual capital in organizations of Agriculture surveyed is effect on the development of knowledge management. And also, intellectual capital in the organization and effective interaction among the organizations can provide to facilitate knowledge management in organizations. Moreover, ability to develop creativity and innovation in the organization increases.

\section{Reference}

Abdolkader, A. h. (2004). "Readiness of IDSC to adopt knowledge management" .knowledge management: Current issues and challenges. Coakes, E. (Ed). London: IRM press, pp11-13

Abou-Zeid, E. (2003). Developing business aligned knowledge management strategy. Knowledge management: Current issues and chal- , (pp. 156-172). IRM Press.

Bahrami, G. (2010). Examining the relationship among social capital and knowledge management in high school girls in Tabriz, Journal of Educational Research, second year, Number four.

Bahrami, G.( 2010). Examining the relationship among social capital and knowledge management in high school girls in Tabriz, Journal of Educational Research, second year, Number four.

Bontis, N. (1998)."Intellectual capital: an exploratory study that develops measures and models", Management Decision, Vol. 36, No. 2, pp. 63-76.

Bontis, N., Keow, W. C. C. and Richardson, S. (2000). Intellectual capital and business performance in Malaysian industries. Journal of Intellectual Capital, 1, 85-100.

Chong, S.C. and Lin, B. (2008). "Exploring knowledge management $(\mathrm{KM})$ issues and $\mathrm{KM}$ performance outcomes: empirical evidence from Malaysian multimedia super corridor companies", International Journal of Technology Management, Vol. 43 No. 4, pp. 285-303.

Davenport,T \& L.prusak. (1998). Working knowledge:how organizations manage what they Know, Boston :Harvard Business School Press. 
Drucker P. (1988). 'The coming of the new organization'. Harvard Business Review, 66(1): 45-53.

Guthrie, J. (2001)."The management, measurement and reporting of intellectual capital", Journal of Intellectual Capital, Vol. 2, No. 1, pp. 27-41.

Ho, C.T. (2009). "The relationship between knowledge management enablers and performance", Industrial Management \& Data Systems, Vol. 109 No. 1, pp. 98-117.

Kurdabadi salehi, S., rezai, H., sabet, S. (2010), Explain the relationship between intellectual capital and knowledge creation in the insurance company>s fourth international conference Insurance (Insurance Management Efficiency: Challenges and Solutions ), Energy Research Institute, 8 December.

Kurdabadi salehi, S., rezai, H., sabet, S. (2010), Explain the relationship between intellectual capital and knowledge creation in the insurance companyss fourth international conference Insurance (Insurance Management Efficiency: Challenges and Solutions), Energy Research Institute, 8 December.

Lepak,D. \& Snell, S.A. (1999). The human resource architecture: toward a theory of human capital allocation and development. Academy of management review, 24(1), 31-48.

Lesser E. and Prusak L. (2002). 'Preserving knowledge in an uncertain world'. MIT Sloan Management Review, 43(1): 101-102.

Li, Yuan. 2009. How Entrepreneurial orientation Moderates the effects of knowledge management on innovation, systems research and behavioral science. Vol.26, Iss.6; pg.645.

Liao, SH. And Wu, Ch. (2010). “System perspective of knowledge management, organizational learnining, and organizational innovation.
Lin, C.; Liu, A.; Hsu, M. L.; Wu, J. C. (2008).»Pursuing excellence in firm core knowledge through intelligent group decision support system", Industrial Management \& Data Systems, Vol. 108, No. 3, pp. 277-296.

Low, J. and Kalafut, P.C. (2002). Invisible Advantage - How Intangibles are Driving Business Performance, Perseus Publishing, Cambridge.

Michael, S and Baldanza. C. (2001). "A System Approach to Engineering a Knowledge Management System." In: Knowledge Management: The Catalyst for Electronic Government, edited by R. C. Barquin, Bennet and S. G. Remez. Vienna, Virginia: Management Concepts; In137pp.8-14.

Nonaka I. and Takeuchi H. (1995). The Knowledge Creating Company. OUP, Oxford.

Prusak L. (2001). 'Where did knowledge management come from?' IBM Systems Journal, 40(4): 1002-7.

Rezgui, Y. (2007)."Knowledge systems and value creation: an action research investigation", Industrial Management \& Data Systems, Vol. 107, No. 2, pp. 166-182.

Riahi-Belkaoui, A. (2003). Intellectual capital and firm performance of US multinational firms. A study of the resourcebased and stakeholder views. Journal of Intellectual Capital, 4, 215- 226.

Scarbrough H., Swan J and Preston J. 1999. Knowledge Management: A Literature Review. IPD, London.

Seetharaman, A., Low, K.L.T., and Saravanan, A.S. (2004). Comparative justification on intellectual capital. Journal of Intellectual Capital. 5(4), 522-539. 
Shih, K. H.; Chnag, Ch. J.; Lin, B. (2010).»Assessing knowledge creation and intellectual capital in banking industry», Journal of Intellectual Capital, Vol. 11, No. 1, pp. 74-89.

Shojai, A., baghabanian, M. (2009). The relationship between intellectual capital and organizational performance in the industry of Iran Banks, Journal of Industrial Management Faculty of Humanities, Fourth year , No. 9, pp. 117.:

Skyreme D.J. (1998). Developing a Knowledge Strategy, in Strategy Watcher, Technology Support for Knowledge Management, Mid-American Journal of Business, P. 14-20

Song M, Bij HVD, Weggeman M. (2005). Determinants of the level of knowledge application: a knowledgebased and information-processing perspective. Journal of Product Innovation Management 22: 430-444.

Stewart, A.T. (1997). Intellectual Capital: The New Wealth of Organizations, Bantam Doubleday Dell Publishing Group, New York, NY.

Teece DJ. (2000). Strategies for managing knowledge assets: the role of firm structure and industrial context. Long Range Planning 33: 35-54.

Usoff C.A,.Thibodeau J.C., and Burnaby, P. (2002). The importance of intellectual capital and its effect on performance measurement systems. Managerial Auditing Journa, 17, 9-15.

Yli-Renko H, Autio E, Sapienza H. (2001). AT Social capital, knowledge acquisition, and knowledge application in youngtechnology firms. JT Strategic Management Journal 22: 587-613.

Yuan- Feng Wen. (2009). "An effectiveness measurement model for knowledge management «, Knowledge - based system, Vol .22, pp. 363-367. 